\title{
Alexander Andrason
}

\section{Semantics of the ta construction in Basse Mandinka}

Keywords: African linguistics, Mande family, Manding tongues, verbal system, semantics

\section{Introduction - Standard Mandinka and Basse Mandinka}

Mandinka is the westernmost variant of Manding languages which, in turn, belong to the West branch of the Mande family (Kastenholz 1996: 281, Vydrine, Bergman \& Benjamin 2000 and Williamson \& Blench 2000). Manding tongues form a group of languages (or dialects) which are comparatively mutually intelligible (Wilson 2000: 109). Their most important members are Bambara (spoken language in Mali), Malinké (employed in Guinea) and Mandinka. According to Lewis (2009), Mandinka has approximately $1,346,000$ speakers and is one of various idioms spoken in the Republic of Gambia (510,000), Senegal $(669,000)$ and Guinea Bissau $(167,000$; the quoted numbers reflect the situation from the year 2006).

The language is still greatly limited to colloquial situations. Nevertheless, attempts have recently been made to standardize the spelling (cf. A practical Orthography of Gambian Mandinka 1988 and 1993 or Mandinka English Dictionary 1988 and 1995, as well as Tera 1979) and to promote a more official use of the tongue (for instance a certain radio use of Mandinka). Furthermore, various Muslim and Christian religious texts - such as Kambey kutoo ('New Testament' 1989), Kambey Kotoo ('Old Testament' 1998) and Selec- 
tions from the Writings of the Promised Messiah (1988) - have been published employing the standardized form of Mandinka, giving the language a more respectful literary character and a more uniform shape.

The vernacular described in this article represents a Mandinka variety used in the Upper River Division (the most eastern part of Gambia), more specifically in the area of its capital, Basse (henceforth, the term Basse Mandinka will be used to refer to this regional variant). Before presenting the most important dissimilarities between Standard Mandinka (i.e. the language that has been employed in the works quoted in the previous paragraph) and the vernacular employed in the Upper River Region, it should be noted that Basse Mandinka is spoken in the territory where not Mandinka but Fula and Serehule tribes - and thus idioms - are dominant. Furthermore, in the Basse area another dialectal Manding variety, Jaahanka (clearly distinct from Mandin$\mathrm{ka}$ ) is extensively spoken. As a result, Mandinkas from Basse and its proximities are constantly exposed to other prevailing linguistic organizations and to a system which, albeit similar, is - at least in the speakers' linguistic selfconsciousness - sovereign.

Although Basse Mandinka is highly similar to Standard Mandinka and the overall grammatical structure and linguistic strategies available in the two varieties are almost identical, one may detect certain minor features which distinguish the vernacular spoken in the Upper River Region from the standardized language. As far as phonetics are concerned, while the normalized variety includes only one velar stop in its phonemic inventory (i.e. the consonant $[\mathrm{k}]$ ), in Basse, both the voiceless and voiced variants may be found. Consequently, in various cases - especially in borrowed words - where Standard Mandinka uses an voiceless velar stop [k], the Basse vernacular employs its voiced homologue [g], in accordance with the sound employed in the original lexeme, e.g., Gambiya instead of the standard form Kambiya 'Gambia' or gaadiinoo instead of kaadiinoo 'garden'.

As for the morphosyntactical level, one may detect several characteristics which distinguish Basse Mandinka from the normalized language. First, the following forms and constructions, quite common in Basse, are absent in Standard Mandinka: a genitival (possessive) and pronominal expression, formed by means of the postposition ye (e.g., Laamin ye motoo 'Lamin's car' or $A$ ye bukoo 'His book'); an interrogative and relative pronoun joy 'who, which'; relative pronoun $\mathrm{mi \eta}$ 'which, that, who'; functional lexemes such 
as pasike 'because' and puuru 'to, for'. Second, Basse Mandinka offers alternative forms of morphemes and locutions employed in the standardized tongue (it shall be observed that the standard forms may also be used in Basse). Among the most important variations, one may quote a negative habitual auxiliary muka (A muka a lon 'He does not know it'; a by-form of the standard buka); prepositions / conjunctions $k e$ and $k i$ 'to, in order to' (N naata jay ki motoo say 'I came here to buy a car; by-forms of the regular $\mathrm{ka}$ ); past tense auxiliaries $n a$, ne, ne ( $N a$ a ke 'I did it'; by-forms of the normalized morpheme $\eta a$ ); a possessive construction $n$ ne ( $n$ ne bukoo 'my book'; a byform of the normalized expression $n n a){ }^{1}$

Finally, it shall be noted that Basse Mandinka fails to be a unified tongue with a constant number of rules. There is nothing such as a 'Basse Mandinka norm'. Quite the opposite, there is considerable variation concerning the forms and strategies employed by speakers. For example, the ye genitive is not accepted by all informants. Likewise, speakers disagree when indicating the correct form of the past tense auxiliary for the $1^{\text {st }}$ person singular: $n a, n e$, $\tilde{n} e$ or $y a$. Consequently, Basse Mandinka could be defined as a conglomerate of all possibilities provided by and available to Mandinka native speakers in Basse Mandinka and its proximities (for a detailed review of the differences between Basse Mandinka and Standard Mandinka and a discussion of the status of the variety used in Basse, see Andrason 2012).

\section{Objective and method of the study}

In the present paper, we aim at familiarizing the reader with one feature of Basse Mandinka, namely the meaning of a component of its verbal system - the ta construction. This formation, exemplified in (1), has been labeled as the $t a$ construction due to its main structural property: it is derived by adding the suffix $-t a$ to the verb. The gram ${ }^{2}$ is invariably intransitive and its transitive homologue is formed by employing the $y e_{1}$ periphrasis: $A$ keta 'It was / is done' versus $A$ ye a ke 'He had done it / he did it'; cf. Andrason 2012).

${ }^{1}$ One should note that some of these characteristics are not restricted to Basse Mandinka but may likewise be found among other territories.

2 The term 'gram' will be used as a synonym for a grammatical formation, grammatical expression, grammatical construction, etc. 
(1) $\mathrm{N}$ naata ${ }^{3}$ suwo kono

I come-TA home in

I came home

Besides the $t a$ expression, the verbal system of Basse Mandinka consists of the following constructions which, contrary to the above mentioned gram, are all formed analytically: $y e_{1}$ gram - a perfect-perfective-past and stative category (e.g., A ye a say 'He (has) bought it'); ye 2 gram - a modal subjunctive category (e.g., A ye naa 'May he come!'); $k a$ gram - a present and past habitual-progressive category (e.g., $A$ ka a ke 'He does it'); kay gram - present and past progressive category (e.g., A be siinoo kay 'He is sleeping'); si gram - a prospective and modal category (e.g., I si a ke 'You will do it / you must do it'); be...la gram - an intentional prospective category (e.g., $M$ be a faa la 'I will kill him'); naata gram - a perfect-perfective category (e.g., A naata ke 'It (has) happened'); be naa...la gram - a future perfect and past conditional category (e.g., A be naa faa la 'He will have died / He is almost dead'); be ... riy gram - a stative-progressive category (e.g., A be keriy 'it is happening'); nominal be...la gram - a progressive past-present-future category (e.g., $M$ be seneroo la 'I am cultivating'); nominal be..kay gram - a progressive presentpast category (e.g., $M$ be safeeroo kay 'I am writing'); and several tara grams - progressive and stative categories (e.g., $N$ tarata siinooriy 'I am sleeping'; the terms which designate these verbal grams make reference to a specific entity (or entities) employed when forming a corresponding locution). It shall be emphasized that the meta-linguistic explanations of the forms listed above do not account for the entire semantic potential of the grams which usually combine the ideas of tense, aspect, taxis and mood (sometimes also affirmation/negation). Rather, they are designed as general labels which inevitably simplify the real state of affairs. Additionally, the language includes two nonverbal predicators: $b e$ (in negative $t e$ ) and $m u$ corresponding to the English present and past forms of the verb to be (cf. Creissels 1983). For a comprehensive discussion of the Basse Mandinka verbal system and detailed description of the semantic load offered by its constituents, see Andrason (2012).

The $t a$ expression - a component of the Basse Mandinka verbal organization which constitutes the topic of this article - has received a rather limited

3 The relevant Mandinka forms in the ta construction will be given in bold type. The verbs employed in the $t a$ formation will be glossed as TA. 
interest among the scientific literature, which is moreover almost invariably restricted to the standard language. The formation has been defined in different manners, for instance, as an aorist of neuter - i.e. intransitive - verbs (Macbrair 1842: 16), as a completive aspect and past tense (Gamble 1987: 17 and Colley 1995: 15), as an intransitive past (Dramé 2003: 47, 91), as an intransitive perfective-completive positive (Creissels 2008: 77, 2010a: 3, 2010b: 3 and 2007, cf. also Rowlands 1959, Spears 1965 and Long 1971). In particular, in his grammar, Creissels (1983) classifies the form as a stative with two primary semantic nuances: ongoing state and completed action. Under his analysis, the construction can be employed in both the present and past time as well as, denoting future eventuality, in conditional sentences (cf. also Wilson 2000: 112).

No article or monographic study dedicated solely to the semantics of the ta formation has been published thus far. And in particular, no such analysis has been offered for the vernacular employed in Basse. This paper aims at nullifying this lacuna and offers a thorough presentation of the tense-aspectmood-taxis properties of the $t a$ construction as they appear in Basse Mandinka. However, in doing so, we not only aspire to provide a detailed description of the semantics of the $t a$ form in the vernacular found in the capital of the Upper River Region, we also believe that our research may be profitable for Mandinka dialectology and especially, for a more detailed analysis of the $t a$ expression in the standard literary language. It shall also be acknowledged that we will not discuss structural and morphosyntactical properties of the construction such as, for instance, intransitivity and its relation to transitive forms (for a detailed analysis of the phenomenon of valency, and thus that of (in)transitivity, see Creissels (2011).

The purely analytic character of the paper does not signify that our objective is scientifically poor or less ambitious than goals designed in more synthetic studies. Mandinka - both the standard and Basse varieties - is a language whose grammatical description is still incomplete. In particular, a great number of descriptive surveys are required in order to reach a comprehensive picture of the Mandinka verbal system. Only once the most important components of the verbal organization have meticulously been described, a synthetic explanation will be possible (for a more synthetic treatment of the Basse Mandinka verbal system and, in particular, an explanation of the interrelations among its components, see Andrason 2013). 
The present article is a result of an extensive field research carried out by the author in the Upper River Region in 2010 and 2011, and dedicated to writing a Basse Mandinka grammar (cf. Andrason 2012). For that purpose, ten Mandinka native speakers have carefully been selected in order to represent different age groups and educational, professional or even ethnic backgrounds. At the end of the research activities, a massive database was assembled - a record of some 5.000 entries/phrases in which each example was recorded with audio-video instruments and thoroughly discussed with the following informants: Keba Susso (13 years old, male, primary school student, Bassending), ${ }^{4}$ Malick Susso (18, male, high school student, Bassending), Musa Yaffuneh (24, male, watchman, Basse), Lamin Manneh (25, male, university student, Manneh Kunda), Mamanding Sanyang (27, female, nurse assistant, Basse), Musa Sanneh (29, male, driver, Kaba Kama), Baba Kamara (30, male, teacher, Mansajang), Saikou Drammeh (45, male, nurse, Basse, originally from Brikama), Kumba Jallow (56, female, cook, Mansajang) and Mariama Mendy (32, female, nurse, Basse - originally from Fulla Bantang). ${ }^{5}$

Finally, it shall be observed that all the examples provided in this paperand extracted from the author's database - may be classified into three sorts: some were spontaneously produced by speakers, others were formulated by informants under the request of the author in order to study a given grammatical phenomenon, and finally, yet another group was inspired by written texts (Bible translation and Muslim literature) but again, pronounced and, if necessary, reformulated by the above-mentioned persons.

\section{Semantic properties of the $t a$ formation - the evidence}

In the present section of the paper, we will provide a detailed description of the semantic load of the ta gram, specifying all possible shades of meaning offered by the locution. Since our study - as well as the database from which the evidence has been extracted - is concerned with semantic diversity, all the values presented below (with the exception of the performative function, limited to a few verbs) are treated as equally common and significant.

${ }^{4}$ In the parentheses, the name, age, occupation and residence place of each informant will be indicated. The list has been arranged in accordance with the age of the informant.

5 The last two informants are entirely bilingual: Fula-Mandinka and ManjagoMandinka. Their ethnic background is Fula and Manjago respectively. 
In our record, all such meanings are illustrated by an almost identical number of examples. In the real world, the amount of these illustrative cases may be extended ad infinitum so that, per se, there is no difference in their relevance for the total semantic content of the $t a$ formation. The concepts of prototypical and marginal values are related to corpus linguists and to pragmatic factors - certain uses are more prototypical or marginal in determined contexts or types of discourse. To establish such a difference in frequency of meanings displayed by the $t a$ gram, several studies are needed where different corpora and different pragmatic environments will be examined. Such an analysis obviously exceeds the ambit of this article.

The $t a$ construction is frequently employed as a resultative present perfect of current relevance. In such a use, it offers a clear resultative value indicating that certain effects of a previously accomplished action are still available and pertinent to the present state of affairs:

(2) a. A funtita le he go.out-TA EMPH ${ }^{6}$ He has left (i.e. he is not here)

b. A taata marisewo to he go-TA market to He has gone to the market (i.e. he is still there)

c. A naata suwo kono he come-TA home in He has come home (i.e. he is at home)

d. Fo itelu jiita? whether they descend-TA Have they come down? (i.e. are they here downstairs?)

e. A boyita he fell.down-TA He has fallen down (i.e. he is on the floor)

f. N ñinata $i$ too la I forget-TA his name with/at ${ }^{7}$ I have forgotten his name (i.e. I do not remember it)

${ }^{6}$ The lexeme le is an emphatic particle which will be glossed as EMPH.

7 The word $l a$ is a postposition with a broad range of uses and values. Hereafter, we will gloss it as 'with/at' (cf. however, footnote 9 below). 
g. İ moota katiroo ye le fokabay they be.ripe-TA harvesting for EMPH already They are already ripe for being harvested

h. Wo moo kiitiita le fokabay that person be.judged-TA EMPH already That person has been already judged (i.e. he has been condemned)

The ta category is also employed with the sense of an inclusive perfect, denoting that a given action or state has been continuing for an uninterrupted period of time from a particular moment in the past unto the present day:

(3) a. M faamata taa la Banjul ${ }^{8}$ baake I fail-TA go to ${ }^{9}$ Banjul very-much

I have not been to Banjul for a long time

b. M faamata $i$ je la baake I fail-TA you see to very-much

I have not seen you for a long time

c. N faamata suboo domo la bake I fail-TA meat eat to very-much I have not eaten meat for a long time

d. Alitolu le mu moolu ti, mennu nin nte tententa n na marisakuwolu kono

You EMPH are people EXIS ${ }^{10}$ who with me continue-TA I of ${ }^{11}$ temptations in

You are those who have continued with me in my temptations

e. Nte tarata ali fee le fo waati jay saayin

I remain-TA you with EMPH until time long now

I have been with you for so long now

8 There are three possible words for the capital city of Gambia in Basse Mandinka: Banjulu, Banjunu and Banjuloo. Moreover, the first two lexemes commonly lose their final vowel, yielding forms such as Banjul and Banjun.

9 In this example, the lexeme la may be analyzed either - in accordance with what we stated in footnote 7 - as a postposition 'with/at' or as an infinitive marker 'to'.

10 The lexeme $t i$ is an existential particle that accompanies certain verbs with the meaning of 'be' or 'become' (e.g., $m u$ in our example). It will be glossed as EXIS.

11 The slot $n n a$ (i.e. $n / \eta+l a$ ) corresponds to a possessive adjective with the meaning of the English $m y$. 
f. Ate faata kabirin 2003

he be.dead-TA since 2003

He has been dead since 2003

The function of an inclusive perfect is particularly frequent with adjectival verbs (on the values displayed by adjectival verbs, ${ }^{12}$ i.e. verbs which correspond to Indo-European adjectives, see below in this section):

(4) a. N kuuranta kabirin 1992

I be.sick-TA since 1992

I have been sick since 1992

b. Nin kewo finkita kabirin a wuluuta

this man be.blind-TA since he was.born

This man has been blind since he was born

The formation may also suggest that a given resultative activity has repeatedly occurred, approximating an iterative present perfect:

(5) a. N ketuta siiñaa jamaa bii

I faint-TA time many today

I have fainted many times today

b. I naata jay siiñaa jelu?

you come-TA here time how-many

How many times have you come here?

c. A podita siiñaa fula

he jump-TA time two

He has jumped twice

The construction is also acceptable in the experiential perfect sense. In this use, the event expressed by the verb constitutes a subject's experience that has taken place at least once during his or her lifetime. The current relevance nuance is still unmistakable, but the resultative value ceases to be pertinent.

12 This group of predicates is usually denominated as 'stative verbs'. 
(6) a. Ite nene taata Gambiya? you ever go-TA Gambia

Have you ever gone to Gambia? (but you may have come back)

b. Haa, n taata Gambia

Yes, I go-TA Gambia

Yes, I have been to Gambia (but I may have returned)

The $t a$ formation may likewise be employed with the force of an indefinite past or, using an alternative denomination, indefinite perfect. In that function, although expressing events that belong to the past time sphere, the construction fails to be introduced by words that would explicitly locate the activity in a precise moment of past time, e.g., adverbs or adverbial locutions such as yesterday, a week ago etc. Put differently, while the ta form undoubtedly connotes a past action, its definite temporal location is not overtly specified:

(7) N naata Banjul, añin $n$ taata Basse, añin m muruuta Birikama I come-TA Banjul, I go-TA Basse, and I return-TA Brikama I came to Banjul, I went to Basse, and I returned to Brikama

The locution is sometimes found with the performative force, approximating the performative perfect of languages such as Arabic, Biblical Hebrew and Akkadian. In such cases - limited in Basse Mandinka to a few roots that are already performative by nature, i.e. verbs of giving and endowing as well as verba dicendi - the sole fact of pronouncing the sentence is equivalent with performing a certain act:

(8) a. N sonta a la!

I agree-TA it with/at

I agree with that!

b. N sonta a ma!

I agree-TA him with

I agree with him!

However, the ta construction can also be used with an explicit past reference, being thus accompanied by past time adverbs or phrasal expressions and functioning as a prototypical definite past. In this usage, it may appear in 
contexts with different degrees of remoteness or temporal distance from the enunciator's here-and-now. It is found in environments that point to immediate-hodiernal (9.a), recent-hesternal (9.b and 9.c), general (9.d, 9.e and 9.f) and remote (9.g) past moments:

(9) a. Waati jumaa le i naata? $\mathrm{N}$ naata waati wooro kooma.

Time which EMPH you come-TA? I come-TA hour six ago

When did you come? I came six hours ago

b. Dindino wuurita buyo kooma kunuy child shout-TA house behind yesterday

The child shouted behind the house yesterday

c. A siinoota kunuy hoteloo to she sleep-TA yesterday hotel at She slept yesterday at the hotel

d. N naata jay luy luulu kooma I come-TA here day five ago I came here five days ago

e. A taata Gambiya sanji tan kooma he go-TA Gambia year ten ago He went to Gambia ten years ago

f. A keta sanji naani kooma it happen-TA year four ago It happened four years ago

g. Mansa doo nene sotota. A naata Gambiya... king certain once be-TA he come-TA Gambia... Once upon a time there was a king. He came to Gambia...

As far as the aspectual value of the past time ta gram is concerned, the formation frequently introduces perfective - unique and punctual - events:

(10) a. N taata Banjul kunuy talay saba I go-TA Banjul yesterday at three I went to Banjul yesterday at three

b. A faata kari fula kooma he die-TA month two ago He died two months ago 
However, in various instances, the construction corresponds rather to a simple past. It is also able to denote past activities and situations of an extended duration, approximating a durative past:

(11) a. N sabatita Banjul sanji fula. Saayin m muruta Basse. I live-TA Bunjul year two. now I have.returned Basse I lived in Banjul for ten years. Now I have returned to Basse

b. Sanji jelu i jiyaata Basse? year how-many you lodge-TA Basse For how many years have you lived in Basse?

c. Aduy a nin wulakono daafeno tarata jee fo tili tay naani and.then he with wild creatures be-TA there during day ten four And for forty days he was there with the wild beasts

d. $\mathrm{N}$ tarata jee fo tili fula I be-TA there until day two I stayed there for two days

e. Juudankoolu nin Jerusalemunkoolu bee taata Yaayaa kay Judea-people and Jerusalem-people all go-TA John to All the people of Judea and all the people of Jerusalem were going out to John

f. Kurayo naata kunuy suutoo bee electricity come-TA yesterday night all Yesterday the electricity was on the whole night

g. Feetoo sotota Basse feast be-TA Basse A feast was (being celebrated) in Basse

h. A keta mansa ti le fo sanji tan naani he be-TA king EXIS EMPH until year ten four He was king during forty years

The durative value, similar to the imperfective past, is particularly evident and common with adjectival verbs:

(12) a. N konkota nuy

I be.hungry-TA then 
I was hungry (cf. Spanish translation tenía [imperfective past] hambre)

b. A kuuranta le waati jamaa he be.sick-TA EMPH time many

He was sick for a long time (cf. Spanish translation estaba [imperfective past] malo)

c. N saasaata fo luy luulu

I be.sick-TA until day five

I was sick during five days (cf. Spanish translation estaba [imperfective past] enfermo)

The imperfective sense may clearly be observed in the following narrative passage where the $t a$ form co-occurs with the habitual-progressive-imperfective construction $k a+$ infinitive (ka karandiroo ke 'he used to teach' and ka taa sabati 'he used to go to dwell') providing an iterative (or iterative-progressive) sense:

(13) a. Luy-wo-luy Yeesu ka karandiroo ke nuy...

Everyday Jesus used-to teaching do then...

Everyday Jesus used to teach (was teaching)...

Bari sutoo a ka taa sabati konkoo le to...

but at-night he used-to go stay mount EMPH at...

but he used to go out and spend the night on the mount...

Aduy soomandaa juunoo, moolu bee naata

and morning early people all come-TA

and early in the morning people used to come

It is likewise important to note that the ta form of the verb tara 'be, remain, abide' is commonly employed to generate locutions which approximate the progressive past, such as the English expression was doing from a typological perfective, past progressive constructions are frequently derived using auxiliaries which appear in the imperfective (cf. Spanish estaba leyendo 'he was reading') or simple past (cf. Icelandic hann var ao lesa 'he was reading'), but not in the perfective past tense. This would hence harmonize with the nonperfective value of the $t a$ formation, discussed in the previous paragraphs.

(14) a. Ì tarata jalakaroo le la 
they be-TA sewing.net EMPF with/at

They were mending the nets

b. Finkintee doo le tarata siirin silabaloo la blind certain EMPH be-TA sitting roadside at A blind man was sitting by the road

c. A tarata yankankati kay he be-TA be.in.torment at He was being tormented / he was in torments

The prototypical perfect value of anteriority - besides being available in the present temporal sphere (cf. examples 1-6 above) - may also be observed within the past and future time frame. This means that the $t a$ construction can function as a past perfect (pluperfect, 15.a-e) and - although exclusively in subordinate temporal clauses - as a future perfect (16.a-e):

(15) a. Kabirin a funtita nay jiyo kono, a ye $m$ je when he went.out-TA to.here water in, he did me see When he had come out of the water, he saw me

b. Kunuy kabirin a naata, $\mathrm{n}$ diyaamuta a la yesterday when he come-TA I talked him with/at Yesterday when he had come I talked to him

c. Ì ye kuwolu je mennu keta they did things see which happen-TA They saw the things that had happened

d. N naata jay, kaatu i faamaa lafita a la I come-TA here because your father want-TA it with I came here because your father had wanted it

e. Jee nin jee ate ye a lon ko semboo bota a bala there and there he did it know that force come-TA him on with/at He knew immediately that the strength had abandoned him

(16) a. Nin i naata, $m$ be diyaamu la i la when you come-TA I am talk to you with/at When you have come, I will talk to you

b. M be taa la, nin sanjiyo teyita

I am go to when rain stop-TA 
I will go when the rain has stopped

c. Ali ñin dookundi, fonin m muruta nay you this make.work/make.use until I return-TA here Make use of it (do business with it) until I have come

d. $\mathrm{N}$ te a domo la kotenko, fonin a naata I am-not eat to again unless he come-TA I will not eat anymore unless he has come

e. Fonin ali tuubita ali la junuboolu la unless you repent-TA you of ${ }^{13} \operatorname{sins}$ with/at Unless you have repented, ali be yankankati la le fanaa ko ñinnu you are be-punished to EMPH too as these you will likewise perish

It should be noted that the ta construction is commonly employed with the conjunction $n i \eta$ 'if' in conditional protases, indicating future hypothetical activities on the accomplishment of which other subsequent future actions and situations depend. Thus, the event expressed in the protasis, both logically and temporarily, precedes the activity expressed in the apodosis.

(17) a. Sooma nin i naata, m be taa la mariseewo to tomorrow if you come-TA we are go to market to If you come tomorrow we will go to the market (i.e. you will come and then we will go to the market)

b. Nin Laamini naata, mol be karay na if Lamin come-TA we are study to

If Lamin comes we will study (i.e. first Lamin will come and then, if this is accomplished we will study)

The $t a$ formation may also appear in unreal counterfactual conditional phrases:

13 The slot ali [you] la [of] corresponds to a possessive adjective of the $2^{\text {nd }}$ person plural, such as the English word your. 
(18) a. Nin ali naata, ali be seewoo la nuy if you come-TA you are rejoice to then If you had come, you would have rejoiced

b. Niy ite muruta nuy, tennuy nte baarinkewo te faa la nuy If you return-TA then, so.then my brother is.not be.dead to then If you had returned, my brother would not have died

With qualitative adjectival (stative) roots and certain intransitive verbs, the $t a$ formation equates a simultaneous-resultative, indicating that the present condition or quality has been acquired due to a previously performed action: ${ }^{14}$

(19) a. Dokoo faata le bottle be-full EMPH

The bottle is full (i.e. it has been filled out and now it is full)

b. M bataata

I be.tired-TA

I am tired (I have gotten tired and now I am tired)

c. N kamfaata

I be.angry-TA

I am angry (I have gotten angry and I remain angry $)^{15}$

14 This value is similar to that which is offered by the resultative perfect of current relevance (cf. example 2). The main difference consists in the fact that, this time, it is the static situation, condition and quality which are attributed with prominence while the previous event is merely suggested. The internal semantic arrangement of the resultative perfect is quite the reverse: the most important portion of the meaning corresponds to the dynamic event, which is somehow related to a present situation.

15 One should observe that the language includes in its verbal system a form which prototypically provides stative meaning with no patent dynamic resultative nuances: $b e$ + participle. In consequence, if one wishes to express only the static condition of being full, tired and angry (corresponding to examples 19a.c) without any evident traces of a dynamic resultativity, one can employ the $B E+$ participle construction:

(A) a. Dokoo be faarin bottle is be.full-PART

The bottle is full

b. M be bataarin

I am be.tired-PART

I am tired

c. M be kamfaarin

I am be.angry-PART

I am angry 
However, with various adjectival verbs - in a present or unspecified time frame - the ta formation most frequently offers a present stative value, indicating present qualities or conditions. In this widespread use, the resultative sense is unavailable and thus the meaning of the construction is virtually equivalent to the previously mentioned stative $B E+$ participle (cf. footnote 21).

(20) a. A kandita

it be.hot-TA

It is hot

b. A be kandirin

it is be.hot-PART

It is hot

The present stative situation may be either actual (21.a-g) or permanent (22.a-e):

(21) a. N konkota saayin

I be.hungry-TA now

I am hungry now

b. Bii, a kuuranta le

today he be.sick-TA EMPH

He is sick today

c. Bii, a ñiiñaata baake

today she be.beautiful-TA very.much

Today she is very beautiful

d. A kutunkannayaata baake

he be.arrogant-TA very.much

He is very arrogant

e. A koleyaata

it be.difficult-TA

It is difficult

f. Bii a kandita baake

today it be.hot.-TA very.much

Today it is very hot

g. Sumayaa warata baake 
cold be.big-TA very.much

It is very cold (lit.: the cold is being very intense)

(22) a. Ñin bukoo beteyaata

this book be.good-TA

This book is good

b. Nin taabuloo kutuyaata le

this table be.new-TA EMPH

This table is new

c. A naamenta

he be.wise-TA

$\mathrm{He}$ is wise (wisdom is his permanent quality)

d. Ñin kewo tilinta le

this man be.righteous-TA EMPH

This man is righteous (righteousness is his permanent quality)

e. Kee fula naata jay. İ koyita

man two came here. They be.white-TA

Two men have come here. They are white (as opposite to the blacks)

In yet other cases, the construction does not express qualities but rather indicates simple present activities, approximating thus a simple present tense:

(23) a. A lafita taa la Banjul

he want-TA go to Banjul

He wants to go to Banjul

b. Kadoo sotota le

Money be-TA EMPH

There is money (i.e. money is available)

c. Motoo jarita kodi jamaa le la

car be.worth-TA money many EMPH at

The car is worth a lot of money

d. Maanoo mankita jay ne

rice be.scarce-TA here EMPH

Rice is scarce here

e. N suulata a la 
I need-TA it with/at

I need it

As was the case with the dynamic perfect (anterior) meaning, the resultative-simultaneous, stative and simple temporal values of the $t a$ formation may also be found in the past time frame, yielding past simultaneous, past stative and simple past uses:

(24) a. Soomandaa m bataata baake morning night I be.tired-TA very.much I was very tired in the morning

b. Kunuy a kuuranta yesterday he be.sick-TA He was sick yesterday

c. Nin filimoo beyaata nuy this film be.good-TA then This film was good

d. Mansa lafita a faa la king want-TA him kill to The king wanted to kill him

It is also possible to employ adjectival verbs in the future temporal sphere, although exclusively in subordinated temporal phrases:

(25) Saama, nin ite kuuranta, kana naa jay

tomorrow if you be.sick-TA do.not come here

If you are sick tomorrow, do not come here!

This means that the following sentence - analogue to $24 . b$ - is incorrect:

(26) *N kuuranta le sooma I be.sick-TA EMPH tomorrow Intended meaning: I will be sick tomorrow

One should note that when the $t a$ formation is used as an intransitive counterpart of a transitive verb (e.g., samba 'be taken' vs. a samba 'to take'), thus 
approximating a passive construction, the sense may be both stative (as in English 'is taken') and dynamic ('has been taken'):!

(27) a. A kendeyaata saayin he be.cured-TA now He is cured now (i.e. now he is healthy)

b. Kewo kendeyaata wo loodulaa kilino le to man be.cured-TA that place one/same EMPH at The man was cured (had been cured / he became well) immediately

c. A sambata arijana kono he be.taken-TA heaven in He has been taken (is taken) to heaven

Finally, as for the text properties, the ta formation - besides being regularly employed in discourse and dialogues (cf. examples 1-6) - also functions as a principal (together with the ye construction) narrative form of foreground in either recited or written stories. This use may be illustrated by the following examples extracted from the Bible and subsequently recited by native speakers:

(28) a. Wo to le a wulita jee, a taata Tire maafayo la. that at EMPH he arise-TA there, he go-TA Tyre region at And from thence he arose, and went to the region of Tyre

Kabirin a futata, a dunta buyo kono.

when he arrive-TA, he enter-TA house in

When he arrived, he entered a house

Musu doo tarata jee. A boyita a sinolu koto...

woman certain be-TA there. she fall-TA her feet in

A woman was there. She fell at his feet...

${ }^{16}$ It is hence not surprising that the form a safeeta is commonly used in the translation of the Bible together with the purely stative expression a be safeeriy to render the Greek perfect $\gamma \varepsilon \dot{\gamma} \gamma \rho \alpha \pi \tau \alpha l$ 'it is written / it stands written' (cf. Acts 7.42 a safeeta but Mark 1.2 a be safeeriy). On the other hand, the ta formation of the verb safee may also be used with a dynamic sense, for instance: bukoo safeeta ka bo nte la 'The book has been written by me'. Another example is the verb faa: a faata 'he is dead' vs. a faata ka bo nte la 'he has been killed by me'. 
Wo to le musoo taata suwo kono that at EMPH woman go-TA house in Then, the woman went home

b. Bitun Yeesu bota Tire maafayo la. then Jesus leave-TA Tyre region at Then, Jesus departed from the region of Tyre

A taata ka bo nin Sidoni la ka taa Galilee baa to. he go-TA from Sidoni at to Galilea sea to He went from Sidon to the Sea of Galilee

A tambita ka bo nin saatee tajo la he pass-TA through village ten at He came through the midst of the region of the Ten Towns

Nevertheless, it should be noted that the $t a$ form can also introduce the background (for example, recuperated) information (cf. also examples 15):

(29) Kabirin ì bota Yahuudi diina bendulaa to doron, when they come-TA Jew religious meeting.place at only, As soon as they had left the synagogue, ì dunta Sayimoni nin Anduru la buno kono they entered Simon and Andreas of house in they went to Simon and Andreas' place

\section{Conclusion}

The evidence introduced in the previous section indicates that the ta construction displays the following semantic load. First, in respect to the domain of anteriority ("perfectness"), the $t a$ form approximates a present perfect (resultative, inclusive, iterative, experiential and indefinite; cf. as well, the performative value), pluperfect and future perfect (although only in certain subordinated clauses). Second, the formation is commonly employed as a past tense. In this function, the degree of remoteness spans from an immediate to remote past, passing through the domains of hodiernal, hesternal, recent and general past time. Yet in its role as a past tense, the locution may introduce aspectually perfective actions as well as activities that are normally expressed by simple past tenses (preterites), all the while, offering in some instances 
a durative - clearly non-perfective - sense. Third, determined verbs (in particular, adjectival roots) are employed in the $t a$ construction with the force of a present simultaneous resultative, present stative and simple present tense. As was the case with the concept of anteriority, these three values may also be found with a past temporal reference (past simultaneous resultative, past stative and simple past) and - again exclusively in subordinated clauses - in a future time sphere. Fourth, the $t a$ construction in its passive function may yield both static and dynamic readings. Fifth, the formation is extensively used in conditional protases with a patent modal meaning: it conveys the idea of real future possibility or introduces unreal counterfactual hypothetical situations. And finally, sixth, as for text linguistic properties, the locution appears both in discourse (dialogues) and narratives (written and recited). It is a principal form of the narrative foreground which may, however, also introduce background - for example, recuperated - information.

Our study grosso modo harmonizes with the analysis provided by Creissles (1983) and other scholars (cf. section 1) who view the ta formation in Standard Mandinka as a stative-perfective form, an expression of the ongoing state and completed action in the present and past time frame, additionally employed to convey the sense of future eventuality.

Nevertheless, we have also detected certain values absent in studies published thus far: simple (non-perfective) past, durative past, performative perfect, future perfect and counterfactual unreality. We have also specified all perfect meanings (resultative, inclusive, iterative, experiential and indefinite) and discussed the textual values of the construction. Furthermore, as for the adjectival or lexically non-dynamic verbs, we have offered a more detailed description of their semantic properties. We have divided all such uses displayed by these predicates into three main classes: simultaneous-resultative, stative and simple (present or past) tense.

To conclude, our analysis - although agreeing for the most part with traditional studies - proposes important refinements in the determination of the semantic load of the $t a$ formation in Basse Mandinka. We are convinced that these modifications can in the future be used to similarly improve the description of the $t a$ construction in the standardized language. The results of the present study may furthermore enable scholars to develop more synthetic examinations of the Basse Mandinka verbal system, designing a comprehensive model of its structure and specifying relations among its components. 


\section{Bibliography}

A Practical Orthography of Gambian Mandinka, 1988, Banjul: WEC International.

ANDRASON A., forthcoming 2012, Introducción a la gramática del mandinka de la región de Basse.

Andrason A., forthcoming 2013, The Verbal System of Basse Mandinka. University of Stellenbosch.

Colley S., 1995, Mandinka Grammar Manual, Banjul: Peace Corps The Gambia.

Creissels D., 1983, Eléments de grammaire de la langue mandinka, Grenoble: ELLUG.

Creissels D., 2007, A sketch of Bambara argument structure, Workshop Grammar and Processing of Verbal Arguments, Leipzig, April 20-21, 2007.

Creissels D., 2008, L'incorporation en mandinka, in: D. Amiot (ed.), La composition dans une perspective typologique, Artois: Artois Presses Université, p. 75-88.

Creissels D., 2010a, Transitivity alternations in Mandinka, Workshop on Valency Classes, Leipzig, August 21, 2010.

Creissels D., 2010b, The flexibility of the noun vs. verb distinction in the lexicon of Mandinka, International Conference on Polycategoriality, Paris, October 4-6, 2010.

Creissels D., 2011, Leipzig Valency Classes Project: Mandinka corpus, www.deniscreissels.fr/public/Creissels-valency_classes_project_Mandinka.pdf

Dramé M., 2003, Parlons mandinka, Paris: L'Harmattan.

Gamble D., 1987, Elementary Mandinka (Gambian Studies 20), San Francisco: Gamble.

Kambey Kotoo (Old Testament), 1998, Banjul: WEC International.

Kambey Kutoo (New Testament), 1989, Banjul: WEC International.

Kastenholz R., 1996, Sprachgeschichte im West-Mande: Methoden und Rekonstruktionen, Köln: Rüdiger Köppe Verlag.

Lewis M. P. (ed.), 2009, Ethnologue: Languages of the World, Dallas: SIL International.

Long R. W., 1971, A Comparative Study of Northern Mande Languages, Ann Arbor, Michigan: Indiana University Microfilms.

Macbrair R. M., 1842, A Grammar of the Mandingo Language, London: The Wesleyan-Methodist Missionary Society.

Mandinka English Dictionary, 1988, Banjul: WEC International.

Mandinka English Dictionary. Revised Edition, 1995, Banjul: WEC International.

Rowlands E. C., 1959, A Grammar of Gambian Mandinka, London: SOAS. 
Selections from the Writings of the Promised Messiah, 1988, Tilford: Islam International Publications LTD.

Spears R., 1965, The structure of Faranah Maninka, Ann Arbor, Michigan: Indiana University Microfilms.

TERA K., 1979, Le manding: situations et usages officiels, in: Documents de la réunion d'experts sur l'utilisation des langues africaines régionales ou sous-régionales comme véhicule de culture et moyen de communication dans le continent, Bamako: UNESCO, p. 119-123.

Vydrine V., Bergman T. G. \& Benjamin M., 2000, Mandé language family of West Africa: Location and genetic classification (SIL Electronic Survey Report), Dallas: SIL International.

Williamson K. \& Blench R., 2000, Niger-Congo, in: B. Heine \& Nurse (eds.), African Languages, Cambridge: Cambridge University Press, p. 11-42.

WiLson W., 2000, Creissels's Mandinka Grammar, Journal of West African Languages 28(2), p. 109-124.

\section{Znaczenie formy czasownikowej $t a$ w języku mandinka na obszarze Basse (streszczenie)}

Niniejszy artykuł przedstawia dogłębną analizę znaczeń charakteryzujących konstrukcję czasownikową języka mandinka, tworzoną przez dodanie do tematu czasownika przyrostka -ta (tzw. ta construction). Przedstawione dane - zebrane podczas prac badawczych na terenie miasta Basse i jego okolic we wschodniej Gambii - pozwalają stwierdzić, że formacja ta może funkcjonować jako perfektum (czasu teraźniejszego, przeszłego oraz przyszłego), czas przeszły (dokonany, prosty - tzw. praeteritum - oraz duratywny), statyczny (właściwy i z implikacjami rezultatywnymi) oraz czas teraźniejszy prosty. W użyciu pasywnym opisywana konstrukcja ma zarówno znaczenie dynamiczne, jak i statyczne. Forma na ta jest ponadto używana w poprzedniku (protasis) zdań warunkowych, gdzie - będąc silnie nacechowana walorem modalnym - wprowadza wydarzenia przyszłe, ewentualne i możliwe bądź też sytuacje hipotetyczne, nierealne i kontrfaktyczne. Ponadto w odniesieniu do wartości tekstowych formacja pojawia się zarówno w dyskursie, jak i w narracji (pisanej lub recytowanej). We fragmentach narracyjnych badana konstrukcja wprowadza zwykle wydarzenia należące do pierwszego planu (foreground) historii, bedąc jednak w stanie dostarczać również informacji drugoplanowych (background). 